\title{
The shortcomings of emergency remote teaching in rural settings of Zimbabwe during COVID-19 school closures: Lessons from China's experience
}

\begin{tabular}{|c|c|}
\hline $\begin{array}{l}\text { Authors: } \\
\text { Raphael Nhon } \\
\text { Baba P. Tshotsl }\end{array}$ & $\begin{array}{l}\mathrm{go}^{1} \bullet \\
\mathrm{ho}^{1} \mathbb{0}\end{array}$ \\
\hline $\begin{array}{l}\text { Affiliations: } \\
\text { 'Department } 0 \\
\text { Studies and Co } \\
\text { Literature, Fac } \\
\text { Sciences and } \\
\text { University of F } \\
\text { London, South }\end{array}$ & $\begin{array}{l}\text { f English } \\
\text { omparative } \\
\text { ulty of Social } \\
\text { Humanities, } \\
\text { ort Hare, East } \\
\text { Africa }\end{array}$ \\
\hline $\begin{array}{l}\text { Corresponding } \\
\text { Raphael Nhong } \\
\text { rnhongo@ufh. }\end{array}$ & $\begin{array}{l}\text { g author: } \\
\text { go, } \\
\text { ac.za }\end{array}$ \\
\hline $\begin{array}{l}\text { Dates: } \\
\text { Received: } 13 \mathrm{~A} \\
\text { Accepted: } 23 \mathrm{~A} \\
\text { Published: } 06\end{array}$ & $\begin{array}{l}\text { Aug. } 2020 \\
\text { Apr. } 2021 \\
\text { Aug. } 2021\end{array}$ \\
\hline $\begin{array}{l}\text { How to cite th } \\
\text { Nhongo, R. \& T } \\
2021 \text {, 'The sho } \\
\text { of emergency r } \\
\text { teaching in rur } \\
\text { Zimbabwe duri } \\
\text { school closures } \\
\text { from China's ex } \\
\text { Africa's Public } \\
\text { and Performan } \\
\text { 9(1), a482. http } \\
\text { org/10.4102/a }\end{array}$ & $\begin{array}{l}\text { is article: } \\
\text { Ishotsho, B.P., } \\
\text { rtcomings } \\
\text { remote } \\
\text { al settings of } \\
\text { ing COVID-19 } \\
\text { s: Lessons } \\
\text { xperience', } \\
\text { Service Delivery } \\
\text { ice Review } \\
\text { ps://doi. } \\
\text { psdpr.v9i1.482 }\end{array}$ \\
\hline $\begin{array}{l}\text { Copyright: } \\
\text { ๔ 2021. The A } \\
\text { Licensee: AOSI } \\
\text { is licensed und } \\
\text { Creative Comn } \\
\text { Attribution Lic }\end{array}$ & $\begin{array}{l}\text { IS. This work } \\
\text { Ier the } \\
\text { nons } \\
\text { ense. }\end{array}$ \\
\hline Read online: & \\
\hline 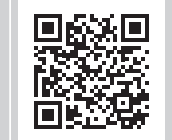 & $\begin{array}{l}\text { Scan this QR } \\
\text { code with your } \\
\text { smart phone or } \\
\text { mobile device } \\
\text { to read online. }\end{array}$ \\
\hline
\end{tabular}

Background: In the wake of the coronavirus disease 2019 (COVID-19) pandemic, schools were forced to close indefinitely with no clue as to when they would reopen. Upon school closures, remote teaching was adopted, with online teaching becoming the most preferred mode of instruction, yet the Information Communication Technology (ICT) infrastructure was not adequate enough across the country.

Aim: This article scrutinises the remote teaching approaches that were put in place in Zimbabwe in response to the closure of schools during the COVID-19 lockdown. The article investigates how the adopted approaches were suitable for conditions in rural settings.

Setting: The study looks at the challenges faced in the implementation of remote teaching during COVID-19 school closures in rural areas of Matabeleland provinces in Zimbabwe.

Methods: The study adopted a qualitative phenomenological approach to analyse the teaching approaches that were put in place by the government and other stakeholders. Twenty teachers from 20 rural schools drawn equitably from two provinces, Matabeleland South and Matabeleland North, were interviewed on the shortcomings of these remote teaching approaches.

Results: The results revealed that the remote teaching approaches that were put in place excluded learners in rural settings. This is because of the challenges in infrastructure, economic condition and restrictions on remote teaching approaches imposed by the government.

Conclusion: As Zimbabwe is facing economic hardships and infrastructure development challenges, it was supposed to adopt emergency remote teaching instead of long-term approaches. A variety of approaches that suit specific physical environments should have been adopted instead of sticking to only one throughout the country.

Keywords: emergency remote teaching; online teaching; rural settings; COVID-19; school closures.

\section{Introduction}

Continuity in education during school closures as a result of coronavirus disease 2019 (COVID-19) lockdown in the first quarter of 2020 required immediate solutions. School closures were meant to maintain physical distancing and, therefore, remote teaching was the most obvious approach that could be adopted to ensure that teaching and learning did not stop. Toquero (2020:186) says that the pandemic has caused global citizens into enforcing widespread community and school closures such that only virtual communication is conceivable to continue learning. There was no time to mobilise resources, so that infrastructure could be set for the smooth implementation of remote teaching. Hodges et al. (2020b) suggested that emergency remote teaching (ERT) was the approach that countries should adopt during the COVID-19 lockdown because its implementation is immediate and requires the use of readily available resources instead of setting up new infrastructure. As traditional teaching abruptly shifts because of the pandemic, remote teaching should be practised in schools worldwide (Affouneh, Salha \& Khlaif 2020). Schools in Zimbabwe, including institutions of higher learning, closed prematurely on the 24th of March when the scheduled closing date was supposed to be 02 April 2020. The lockdown started on 30 March and at the time of writing this article, schools were still closed although they were supposed to have opened on 05 May. Evidence from history reflects that Zimbabwe has never been forced to close schools because of a pandemic but only closed between 1977 and 1980 because of the war of liberation (Dorsey 2006:222). 
In anticipation that schools were not going to open in the scheduled time for the second term, various stakeholders in the education sector started to explore various ways of remote teaching and learning. Online teaching emerged as the only obvious method of remote instruction. The adoption of online teaching excluded the bulk of learners in the rural areas because of lack of pre-assessment of the availability of ICT infrastructure and other factors such as access to the Internet-enabled devices and knowledge of the use of those ICT devices. The response to ensuring continuity in education during the pandemic in Zimbabwe does not consider that the approach to be adopted was not necessarily supposed to be uniform throughout the country and was also not to be a permanent solution. In cases of emergency, teaching and learning in a developing country like Zimbabwe do not necessarily need to adopt sophisticated strategies for continuity in teaching and learning but just those that are simple and compatible with the prevailing economic conditions and available infrastructure.

The arguments advanced in this article in evaluating and making recommendations for Zimbabwe in implementing teaching and learning during the lockdown are hinged on China's experience as it was the first country to witness cases of COVID-19 in Wuhan (Sahu 2020). Although the steps taken by China had many positives, they however did not go without negatives as will be shown in the next section. Apart from online teaching, other measures such as providing lessons through the radio were put in place by the government of Zimbabwe with support from the United Nations International Children's Emergency Fund (UNICEF). However, teaching through the use of WhatsApp was also taking place although this was not regarded as a formal communication channel in education. The article is looking at the perspectives of teachers in view of these remote teaching approaches. The shortcomings of these three approaches are scrutinised in view of China's experience. The article argues that Zimbabwe should have used China's experience as a model in implementing ERT.

\section{Teaching and learning during COVID-19 lockdown in China}

The closure of schools as a result of COVID-19 pandemic affected all countries in the world unlike other pandemics where the effects were only felt in specific countries. At the end of 2002, severe acute respiratory syndrome (SARS) led to the banning of face-to-face teaching in several regions of China, a measure which was taken to curb the spread of the virus (Cauchemez et al. 2014; Huang et al. 2020). Similarly, in 2009, the outbreak of swine flu (H1N1 Flu) affected several people around the world, causing school closures in countries that included Bulgaria, China, France, Italy, Japan, New Zealand, Serbia, South Africa, Thailand, the United Kingdom and the United States of America (Cauchemez et al. 2014; Huang et al. 2000). Countries in the world responded to COVID-19 by implementing nationwide school closures in the first quarter of 2020 (Viner et al. 2020).
To control the spread of COVID-19, China sealed Wuhan on 23 January 2020 and soon expanded lockdown to other 12 cities in Hubei province (Ji et al. 2020:4; Sahu 2020:1). China succeeded in reducing infections by taking aggressive measures such as travel bans, physical and social distancing, self-isolation or quarantine and asking people to work from home (Sahu 2020:1). A more stringent confinement of people seemed to have potential in slowing down the spread of COVID-19 (Lau et al. 2020:1).

China is the first country worldwide to provide massive online education to hundreds of millions of students for the prevention and control of the pandemic (Huang et al. 2020; McAleer 2020). China's experience in teaching and learning during the COVID-19 lockdown is an interesting one because it was the first country to embark on such an exercise (Ji et al. 2020). In response to the outbreak, the Chinese government initiated a series of emergency management mechanisms, including social distancing which translated to the shutting down of schools (Ji et al. 2020; McAleer 2020; Wang et al. 2020). According to Huang et al. (2020), during the COVID-19 outbreak, the Chinese Ministry of Education launched the 'Disrupted Classes, Undisrupted Learning' initiative, providing flexible online learning to over 270 million students. Zhang et al. (2020) used a different term from the one used by Huang et al. (2020). Zhang et al. (2020) referred to the approach adopted by China as 'Suspending Classes without Stopping Learning'. The two terms used by these authors carry the same meaning and the difference could have come as a result of technicalities in translating from Chinese to English.

As a response to the COVID-19 outbreak, the Ministry of Education in China coordinated 22 online courses at the national level (Huang et al. 2020). Resources such as filmed lectures and educational games were put in place to be used in online teaching. The aim was to integrate teaching resources, provide rich, diverse, selectable and high-quality online resources for all students across the country, and support teachers' online teaching and children's online learning (Zhang et al. 2020).

In implementing the policy that guided teaching and learning during the pandemic, the Government of China followed five steps, which are:

- Integrating national resources and planning at top level: The government took an initiative to guarantee the provision of reliable network provisions. The Ministry of Education, together with several telecom operators committed to the maintenance of public service platforms and school networks. The Ministry of Education approved 37 qualified institutions and Internet companies to provide online teaching services.

- Training of teachers: The education administration made efforts to provide training to teachers on online teaching. Schools also complemented the government's efforts by appointing online teaching technology consultants to support online teaching. 
- Enabling local authorities and schools to carry out online teaching in line with local conditions: To ensure the reach of information and resources to all students, including those in remote areas, the government worked on circulating teaching information in multiple ways using satellite TV in areas where there was no Internet coverage.

- Formulating guidelines to prepare for smooth transition back to normal face-to-face education after the epidemic.

- Working a plan for school reopening after the epidemic. A plan to have schools reopen in a staggered manner was put in place (Huang et al. 2020; Zhang et al. 2020).

China's approach could have been used as a benchmark by developing countries including Zimbabwe. The ICT infrastructure in Zimbabwe is so poor that Internet is inaccessible to the majority of learners in rural areas. That situation renders the adoption of online teaching in rural areas impossible.

In China, several web-based platforms were integrated into online teaching and learning and these included DingTalk, National Public Service Platform for Educational Resources, PEP Touch and Read, Rain-Classroom, National Cloud Classroom and One Stop Learning, amongst others (Huang et al. 2020). 'DingTalk' is a multiterminal platform for free communication and collaboration that also supports the mutual transmission of files between mobile phones and computers. This platform offers online teaching, online homework submission and correction, online examination and online conferencing for all teachers, managers and principals (Huang et al. 2020). 'DingTalk' has widely been used in live-streaming classes by a large number of primary and secondary schools in 17 provinces in China to resolve school closures caused by COVID-19 (Huang et al. 2020).

The National Public Service Platform for Educational Resources was meant to meet students' demands during the COVID-19 period and appropriate learning resources were added into this platform. Ten subjects were added into this platform. The Ministry of Education of China emphasised that (Zhang et al. 2020:2):

The knowledge of epidemic prevention and control needs to be included in addition to the formal national curricula, with a special emphasis on the popularisation of the knowledge of epidemic prevention, expressed through life education classes, public safety education and mental health education.

On the first day of the operation on 17 February 2020, the platform was visited more than 8 million times by users from 31 provinces of China and others from other countries outside of China (Huang et al. 2020).

'PEP Touch and Read' is another digital platform that was provided by People's Education Press (PEP). The PEP is a large professional company affiliated to the Chinese Ministry of Education which provided open and free access to all digital teaching resources to primary and secondary schools through 'PEP Touch and Read' platform. The digital textbooks provided through 'PEP Touch and Read' came with thousands of video and audio micro courses synchronised with textbooks (Huang et al. 2020). These digital textbooks involve nearly 600 varieties of more than 20 disciplines. Another platform is 'Rain-Classroom', which is a smart teaching tool with the purpose of enhancing the interaction between teachers and learners, and making teaching online more convenient (Huang et al. 2020). Through 'Rain-Classroom', students can answer real-time questions and interact with teachers through live broadcast. On the other hand, the 'National Cloud Classroom' provides e-textbooks compiled by the education department (Huang et al. 2020).

Four channels of China Education Television started open broadcasting covering 75 lessons on air to provide learning in remote areas without Internet or without cable TV (Huang et al. 2020). China's efforts in the provision of remote teaching are commended in that those learners without access to the Internet were included in education through other means, such as television. In view of China's diverse approaches that were meant to suit each existing ICT infrastructure, the present article argues that Zimbabwe should have also adopted a variety of approaches in the delivery of lessons depending on the available ICT infrastructure in each physical environment.

Although China's approaches to remote teaching during the COVID-19 pandemic are celebrated, it should, however, be noted that the implementation of these approaches did not go without challenges. The difficulties that were faced in the implementation of remote teaching during the COVID-19 pandemic in China include challenges of infrastructure, availability of online teaching resources, teachers' ability and experience to use online teaching, distractions associated with working from home, lack of clarity on the teaching mode and pedagogy that works best for online education (Huang et al. 2020; Zhang et al. 2020). These challenges faced by China should also serve as a lesson to Zimbabwe.

\section{Emergency remote teaching}

According to Hodges et al. (2020b), ERT is a temporary shift of instructional delivery to an alternative delivery mode with the primary objective of providing instructional support that is reliable but easy to create in the time of crisis. Hodges et al. $(2020 a, b)$ are credited for being articulate about ERT and for clarifying its distinction from online teaching. They are the ones who initiated the discourse of ERT during the COVID-19 crisis in 2020. Other researchers who talk about ERT derive their arguments from the work of Hodges et al. (2020a, b). Emergency remote teaching involves the use of fully remote teaching that would otherwise be delivered face to face or as blended instruction (Hodges et al. 2020a, b). To them, the primary objective of ERT in the context of the pandemic is not to re-create a robust educational ecosystem but rather to promote temporary access to instruction and instructional supports in a manner that is quick to set up and is reliably 
available during an emergency or crisis. Hodges et al. (2020a, b) noted that if ERT is understood in this manner, then it should be divorced from online teaching. Hodges et al. $(2020 \mathrm{a}, \mathrm{b})$ explained the distinction between ERT and online teaching. They argued that many countries made a mistake of trying to adopt online teaching which they had mistaken for ERT.

Hodges et al. (2020a) did not only propose ERT as an approach to be adopted during the COVID-19 lockdown, but they also came up with a model that outlines the implementation plan. Hodges et al. (2020a) designed a model for ERT where they outlined key areas that need to be taken into consideration when implementing ERT. These are pre-implementation evaluation, contextual assessment and evaluation of assessment of ERT. On pre-implementation evaluation, they suggest that concerns should be about the critical instructional needs, critical non-instructional needs and the number of learners who would experience accessibility barriers. They suggest that on contextual assessment, the issues to be considered are the major changes in the learning context, number of learners with reliable Internet, phone or mobile service and other Internet-enabled devices, living environments of the learners, available ICT infrastructures, the objectives of learning contents and strategies to be adopted. Evaluation of assessment entails checking whether the assessment yielded enough information to guide ERT design and development (Hodges et al. (2020a). The widespread closure of schools as a result of the COVID-19 outbreak seemed to shock the education community, with many teachers scrambling to figure out how to shift their pedagogy to ERT (Trust \& Whalen 2020:190).

A distinction between online distance education and ERT has also been made by Bozkurt and Sharma (2020). They argued that online distance education involves more than simply uploading educational content, rather it is a learning process that provides learners agency, responsibility, flexibility and choice. Online distance education is a complex process that requires careful planning, designing and determination of aims to create an effective learning ecology (Bozkurt \& Sharma 2020:ii). Emergency remote teaching is currently being practised in many countries and should be considered a temporary solution to an immediate problem (Bozkurt \& Sharma 2020). The attempts that are currently being made in trying to provide education during the pandemic as a temporary solution are actually taking the form of ERT and not distance education (Bozkurt \& Sharma 2020). Whilst distance education has always been an alternative and flexible option for learners, ERT is an obligation which means that we have to use different strategies and approach teaching during school closures with different priorities (Bozkurt \& Sharma 2020:ii). Schlesselman (2020) also made a comparison between online teaching and ERT. In contrast to ERT, online learning is bound by many standards to ensure optimal learning. However, Schlesselman (2020) unlike other researchers argued that online teaching has far more advantages than ERT. Using the right definitions is important because rushing into ERT, calling it online distance education or online learning and assuming online tools to be a form of online distance education should be approached with caution (Bozkurt \& Sharma 2020). These ideas inform the current study by suggesting that Zimbabwe should be adopting ERT instead of online teaching, given the circumstances that are at play.

Emergency remote teaching is unique in that it does not need too much planning, but its implementation has to be instant and abrupt with the utilisation of readily available resources. A regular and comprehensive online learning curriculum will take months before it can be operational to service the students' needs during the pandemic (Toquero 2020:186). Emergency remote teaching offers academic freedom as the teacher can make instructional decisions based on the context of a current situation to maximise the learning opportunities for the students despite the crisis (Toquero 2020:186). Desperate times require desperate measures, and ERT can allow for the possibility of collaboration and exchange of concepts and best practices amongst practitioners, educators and scholars (Toquero 2020:186).

Given the pressing concerns about COVID-19, it is vital to determine the specific term that can be used to refer to the kind of instruction given by the teachers considering that there is an abrupt change in education and that the current model of teaching is interim. As such, ERT should not be labelled as online teaching because it takes various approaches on board (Talidong 2020:196).

\section{Research design and methodology}

In its attempt to understand and explore the approaches that were adopted by Zimbabwe in ensuring continuity in education during the COVID-19 lockdown, this study used a qualitative phenomenological research design.

The study looked at the experiences of teaching and learning in rural settings in Zimbabwe during the lockdown.

The phenomenology design calls for that to understand human experiences, there is a need for immersive penetration of individual's thoughts and insights through employing interviews or extensive discussions (Creswell 2017). The immersive penetration in this study was carried out through interviewing 20 teachers from 20 rural schools. The researchers chose 20 teachers who were equitably drawn from 20 schools because they felt that this number and the distribution were going to be reflective of the experiences of teachers from a variety of schools. The main interest was on Grade 7 teachers because they were taking learners who were to sit national examinations at the end of the year. Of the total 20 teachers, 10 were drawn from schools in Matabeleland South (MS) province and the other 10 were from Matabeleland North (MN) province of Zimbabwe. 
As the study was conducted at a time when travel restrictions were imposed, the interviews with teachers who were purposively selected were carried out through email, phone calls, WhatsApp and Skype depending on the mode with which each of the participants was comfortable. These teachers were interviewed to ascertain the methods that they were using during the lockdown to interact with the learners and also to establish the challenges that they were facing in using such methods. Knowing the methods that were used and the challenges that were faced helped in determining whether their approaches conformed to ERT or not. The data gathered from the research participants were also meant to confirm whether the approaches for teaching and learning adopted during school closures were feasible or not. The information supplied by the teachers was analysed from the perspective of ERT and China's experience in teaching during school closures.

The researchers explained to the participants the overview and focus of the study which is aimed at investigating the challenges that they faced in implementing ERT in the rural settings of Zimbabwe where challenges in ICT infrastructure are coupled with economic hardships. The ethical consideration, such as ensuring the anonymity of the participants throughout the course of the study was explained to them. The actual names of the participants were anonymised through the use of pseudo-names to secure their personal identity and confidentiality. After this article was completed, all raw information from research participants were deleted.

\section{Approaches to teaching in rural settings during the pandemic}

There are three methods of delivering instruction that conformed to remote teaching during the lockdown in Zimbabwe. These methods include online teaching, using the radio to deliver lessons and the use of WhatsApp. Online teaching and the use of the radio were announced by Zimbabwe's Ministry of Primary and Secondary Education (MPSE) as the official channels of delivering instruction, whilst WhatsApp was considered as unofficial.

\section{Online teaching}

Online teaching was the first method of delivering instruction remotely that was proposed for adoption at the beginning of the lockdown. This was done without any pre-assessment of ICT infrastructure in Zimbabwe.

However, it did not take time for MPSE to dismiss it as the possible method for remote teaching during the lockdown. Online teaching was put aside after the Ministry of Education had realised that it was not all learners who would have had access to online lessons. Although online teaching is part of ERT, it should be noted that it is not ERT on its own if it is not used with other methods which would enable all the learners to access lessons.
The challenge of Internet is not only peculiar to rural areas but even in urban areas there are many other challenges that hinder accessibility to online learning. In a letter addressed to parents and students from one of the elitist schools in the capital city, Harare, the headmaster said:

'At the beginning of May, I compared the new teaching and learning programme to that of non-engineers being asked to "design, build and then take off in a plane within a very short period of time". If I can continue with that analogy, we are now in mid-flight; we experienced some turbulence at the start of the journey but the flight is smoother now and our destination is clear. I am confident that we will land safely and on schedule.' (Headmaster letter, Harare, 23 June 2020)

This letter was written on 23 June 2020, whereas online teaching at this school had started on 29 March 2020 but was not yet perfect. One then wonders what the situation would be like in the rural areas where there is poor or no ICT infrastructure and there are economically disadvantaged people. The headmaster's sentiments are clear testimony that what was required in Zimbabwe was ERT that would have allowed the use of readily available resources instead of trying to use the more obvious but sophisticated online teaching. Online teaching proved not to be as obvious as was anticipated because of inadequacy or unavailability of required resources and ICT infrastructure.

There are two online teaching and learning platforms that have been put in place in Zimbabwe and these are Ruzivo and Akello. Ruzivo is an online interactive digital learning platform targeted at primary and secondary school students (Ruzivo 2019). It was established in 2019 as an initiative of Higherlife Foundation. Higherlife Foundation is an organisation that is centred on empowering communities from primary school to higher education and is a subsidiary of the country's biggest network provider, Econet. Through its Smart Learning platform, Ruzivo is fighting exclusion of the rural student and giving them access to the 21st-century learning approaches in order to develop informed future leaders that can move Africa forward (Ruzivo 2019). Ruzivo Digital Learning is a desire to impact, transform, improve accessibility and enhance education and results of millions of learners in Zimbabwe through the utilisation of innovative technological solutions (Ruzivo 2019).

However, all the 20 teachers who were interviewed said that they were not aware of this learning platform called Ruzivo. Of the 20 teachers, three said that they tried to google this Ruzivo platform but did not get sense of how it works. This is despite the MPSE having emphasised that Ruzivo should be used for maintaining continuity in education during the lockdown (Sunday News, 26 April 2020). The researchers visited the Ruzivo website and noticed that learners have to register so that they can be able to use this platform.

Akello Digital Classroom was launched by Cassava Smartech, a diversified digital services group which falls under Higherlife Foundation and is also a subsidiary of 
Econet. Akello Digital Classroom was launched in Zimbabwe on 28 May 2020, and is a platform that offers Zimbabwean learners from primary level to high school access to online approved curriculum lessons (Chronicle 2020). Akello Digital Classroom has both synchronous and asynchronous lessons where the former is meant for the teacher to interact live with the learners and the latter is for revision after a live lesson.

It has to be noted that whilst Ruzivo was launched as an online learning platform well before COVID-19 pandemic was known, Akello was designed mainly to facilitate learning during and after the pandemic (Chronicle 2020). This implies that these two teaching and learning platforms are not adequately addressing the demands of ERT because they are only accessible to a few learners who have access to Internet and can afford Internet-enabled devices and the Internet data. These two online learning platforms are elitist in that they exclude the bulk of learners, especially those who are in rural settings or are from disadvantaged backgrounds. Although Akello was designed as a response to counter failure to provide education as a result of the pandemic, it did not come as ERT but as a long-term plan. Emergency remote teaching requires solutions to education during the lockdown that accommodate as many learners as possible. Akello and Ruzivo belong to the same company and therefore the need to duplicate Ruzivo through Akello was not required, instead a more accessible-to-all teaching and learning platform could have been designed especially one that could be accessible offline. Huang et al. (2020) and Zhang et al. (2020) noted that China also provided learning through offline packages in areas that had no Internet network. Whilst online teaching carried out through synchronous or asynchronous tasks have been favoured, it is significant to consider other modes of learning delivery, such as the use of modular-based, and not just solely relying on the online platforms (Alvarez 2020:149). Although the response to stoppages in education by the initiators of Akello and Ruzivo is highly applauded, they should also have at least designed a learning platform that would also accommodate learners from disadvantaged backgrounds, especially those in the rural areas.

The teachers who were interviewed about how they engaged with learners in rural settings during the lockdown said that there were a number of challenges that included ICT infrastructure, access to Internet-enabled devices, knowledge of the use of ICT devices and unaffordability of Internet data. A sudden shift from a fully traditional learning environment to remote teaching is considered to be problematic. It is no wonder that prior to this untoward event, the existence of issues on accessibility and affordability has been a nationwide problem. Therefore, moving learners from a culturally face-to-face design to online teaching with impending issues of reliable Internet coverage, high cost of technological devices and financial constraints can cause learning disruptions (Alvarez 2020:150). It should be noted in data presentation that MN stands for Matabeleland North, whilst MS stands for Matabeleland South. One of the participants said:

'Online teaching can be a great challenge to rural schools. Let's consider schools like Gomoza primary where there is no electricity. For instance, there is an NGO called Profoture which donated ICT gadgets such as tablets, laptops, projector, etc. They wanted to ensure that the school embraces technology in all aspects but we are failing to make use of those gadgets because we don't have electricity. Moreover, there is a network problem at Gomoza so doing online teaching can also be a challenge as it requires one to have network access. Learners in Gomoza are also ICT illiterate since they have less exposure to ICT tools. Learners can't even do simple things such as switching on a smartphone because they are rarely exposed to smartphones, so online learning can be very difficult.' (Nothando, Teacher, MN)

The unavailability of mobile network and electricity was the infrastructural challenge that the majority of teachers identified as impeding the implementation of remote teaching in rural settings. A teacher said that:

'In Beitbridge West Zimbabwe's network is a challenge in most areas Dombo, Madali, Mtangamchena, Masera, Toporo-no network at all. Shashe no network at all ... Parents are relying on SA networks which at times cut off hence online learning might be a challenge to the rural child.' (Dick, Teacher, MS)

\section{Others pointed out that:}

'Online teaching is a real challenge to most rural areas, e.g. places like Gokwe South schools like Kasuwe, Ngani, Manyoni, Chamatendera, Huchu, Masosoni and Chireya Simuchembu1 and 2 in Gokwe North just to mention a few where there is no electricity.' (Mamba, Teacher, MN)

'No network coverage. We use Botswana network Mascom and Orange which is expensive to buy using Pula. Most learners are not computer or ICT literate. Network is at certain points one has to go to that point to access what has been sent.' (Sibo, Teacher, MS)

The narration about Internet network in Silozwe area in MS was as follows:

'Poor network or unavailability of mobile network is another challenge faced, e.g. some places still do not have viable network system and if it's to be done online, those on digital divide wont access the lessons, for example Silozwe network is poor that not it can't just google and so online education will be more of those with, than those without network and resources to access network will only be accessible to those with gadgets and money, meaning online education is only going to embrace the elite mostly and ignore the plight of the poor and those on digital divide.' (Talan, Teacher, MS)

\section{Another said:}

'Even though a few pupils may have the gadgets, power source is the greatest challenge. In our case (Simchembu community) there is completely no power source. There is no electricity. Very few have solar systems. This creates another barrier to online learning. In our case and other neighbouring schools, the gadgets are not even known physically by pupils. In the case of the Internet data bundles are no longer affordable. Like these days Econet private Wi-Fi bundles have been increased from ZW\$400 for 25GB up to ZW\$1300 the same 
bundles which then calls for even those working not able to purchase them.' (Mpo, Teacher, MN)

These concerns are clear testimony that not enough factfinding was done before trying to implement teaching during the COVID-19 lockdown. The ardent subscribers of ERT, Hodges et al. (2020a, b) suggested that during a crisis, proper planning has to be done before implementing remote teaching. Before making an extensive assessment of available infrastructure across the country, Zimbabwe opted for online teaching as it was the most obvious method that would suit remote teaching. The policymakers did not consider that online teaching alone would not suffice as ERT as the bulk of learners in the country did not have access to ICT devices and infrastructure. The COVID-19 pandemic has come as a wake-up call as it has shown that a sudden shift from traditional classroom instruction to ERT can bring disaster on part of the students' learning process (Alvarez 2020:149). Although the learning technologies are becoming part of instructional integration in a face-to-face classroom, it is also no doubt that in developing countries, like Zimbabwe, it poses different challenges like accessibility and affordability (Roberts \& Hernandez 2019).

From the responses, it is also clear that teachers were not empowered prior to implementing remote teaching. The successful implementation of ERT is in the hands of the teachers as they are the catalyst of learning (LaBonte 2020). Hence, teachers should be empowered with the necessary techniques for delivering remote teaching (Bates 2020). Because of the challenges outlined above, online teaching failed to be adopted by the MPSE of Zimbabwe and the use of the radio was opted as the best option.

\section{Radio as a teaching and learning tool}

Radio appeared to be the most favoured platform for remote teaching during the pandemic because of its accessibility. The accessibility of radio signal is better as compared to Internet network in the remote areas of Zimbabwe. In seeing the advantages of using radio over Internet, the government proposed that lessons were to be delivered through the radio. The Deputy Minister of Education said that as the school calendar had been disrupted because of COVID-19, his ministry had reached an agreement with Zimbabwe Broadcasting Corporation (ZBC) to have lessons broadcast through radio (Sunday News, 26 April 2020). The MPSE indicated that material would be printed and distributed to rural communities that have no access to radio (Sunday News, 26 April 2020).

On the same note, the UNICEF Regional Chief of Communication in Eastern and Southern Africa, James Elder, said that his organisation was talking to governments in Southern and Eastern African countries so that radios were used to reach out to children during the lockdown. This was revealed in an interview on South African Broadcasting Corporation (SABC 1) television on 04 May 2020. He said that English and other learners' first languages were going to be used in conducting lessons over radio. The United Nations International Children's Emergency Fund (UNICEF 2020) raised concern that over 127 million school children in Eastern and Southern Africa who were supposed to return to school in the week beginning 04 May 2020 remained at home as a result of COVID-19 outbreak. Upon noticing that $84 \%$ of these children live in rural areas where there is no electricity and no Internet connection, making it impossible for these learners to access online lessons, UNICEF decided to provide these lessons through radio in each of the countries that they are working with, including Zimbabwe (UNICEF 2020). The United Nations International Children's Emergency Fund is aware that of the 127 million children, radio will reach only 53 million of those children across Eastern and Southern Africa (UNICEF 2020). The organisation has, therefore, proposed that those children who are not reached by radio will be catered for through printed material.

From the similarities in information concerning the use of radio in delivering lessons by the Ministry of Education of Zimbabwe and UNICEF, it is clear that the two are jointly working and they are collaborating.

This also came to light during the launch of radio lessons at Montrose Studios in Bulawayo on 05 June 2020. However, when radio lessons were launched, it is only three primary school grade levels that were covered, with secondary school not totally catered for. Some Early Childhood Development (ECD) lessons will be broadcast on National FM, whilst Grades 3 and 7 pupils will receive their radio lessons on Power FM, Classic 263, Radio Zimbabwe and Khulumani FM. Grades 4-6 pupils are not covered in the first schedule (Chronicle 2020). It has to be noted that these radio stations are not solely dedicated for education, but they are also used for broadcasting many other programmes like news, entertainment, current affairs and so on. It is unlike in China where a whole radio or television station would be dedicated for education. Although the MPSE made efforts in trying to have remote teaching being carried out through radio, the approach did not adequately address the need for effective remote teaching during the crisis.

Despite radio being the best chosen option, learners in some rural settings are still facing some challenges as there are no radio signals in their geographic locations. The teachers who were interviewed all agreed that with the present ICT infrastructural setup in Zimbabwe, radio is the best mode of delivering lessons. They, however, raised concern that there are a number of remote areas in the country where there are no radio signals.

\section{Observation was as follows:}

'The option by the government to offer lessons through the radio is much better but with our case and other neighbouring schools is again a non-starter. Yes, almost every home has a 
radio but just for playing recorded music as the channels are unreachable as well, for example, Radio Zimbabwe. With FM radio station, is only better when on top of a mountain. Then the question is, how many times will a person climb a mountain?' (Mpo, Teacher, MN)

One also wonders if it is going to be possible for learners in these remote areas without radio signal to get the hard copies that are the same as those lessons that are broadcast on radio. The teachers who were interviewed said that they have not heard of any school that has received the printed lessons:

'I am the head of the school and my home is closer to the school but I have not received any teaching or lessons material. I only read about it on newspaper where the minister was talking about areas like ours where there are no radio waves. We are still waiting for those booklets, maybe they will come one day.' (Mamba, Teacher, MN)

This is a clear sign that prior planning was not properly carried out because some learners are being excluded in this mode of teaching that was said to be the most ideal amongst other approaches.

\section{Teaching and learning through WhatsApp}

Although WhatsApp is not treated as a formal channel of education in Zimbabwe, teachers said that it is one of the most efficient modes. As our societies transition from the Information Age to the Social Media Age, education is one area that struggles to make sense of that transition (Ostashewski \& Reid 2013). The teachers indicated that despite being regarded by MPSE as an unofficial channel of communication in education, WhatsApp has proven to be the most preferred by teachers and learners for its ease of accessibility, real time and efficiency. Bouhnik and Deshen (2014) concluded that WhatsApp created a conducive learning environment amongst learners through creating an atmosphere that supported interaction, sharing of content and intense collaboration amongst the peers.

The research participants who were advanced-level teachers said that they were reaching out to their students through WhatsApp. They pointed out that this mode of teaching did not start as a response to the COVID-19-induced lockdown, but they have always engaged with the learners through WhatsApp groups during weekends and school holidays although the MPSE does not allow them to use it in teaching. One of the teachers said:

'WhatsApp use although a very effective way, network is the greatest barrier. It may be faster in reaching the learners but there is no convenient network. Another impediment is of purchasing the bundles. With our school and other surrounding areas, people depend on farming. This year there is drought and therefore people have no money.' (Mpue, Teacher, MS)

Although WhatsApp is one of the most convenient ways of facilitating remote teaching, its effectiveness is hampered by the unavailability of mobile network, lack of access to Internet-enabled gadgets and unaffordability of Internet data.

The Amalgamated Rural Teachers Union of Zimbabwe (ARTUZ) launched WhatsApp classes for learners from rural schools on 01 April 2020 (Kubatana 2020). These WhatsApp classes were launched during the lockdown to cater for examination classes which included Grade 7, Form 4 and Upper 6. As of 20 April 2020, 920 Grade 7 learners, 2460 learners doing Form 4 and 900 learners doing Upper 6 were part of the WhatsApp classrooms conducted by ARTUZ (Kubatana 2020). The efforts made by ARTUZ were deliberately not taken into recognition by the government most probably because ARTUZ is known as a teachers' labour union and also that they did not involve the government through MPSE in their planning.

\section{Conclusion}

As a developing country with no adequate ICT infrastructure, poor radio signal in rural areas and facing economic hardships, Zimbabwe should have come up with a clear and realistic model of ERT instead of trying to implement a uniform approach of reaching out to the learners across the country during the lockdown. It is clear that Zimbabwe wanted to adopt a uniform remote teaching approach without making an assessment of available resources and infrastructure. As a country that is facing infrastructural development challenges and economic hardships, Zimbabwe should have adopted varied approaches that were going to enable the delivery of same information to the learners throughout the country. Learners in both rural and urban settings were disadvantaged because of this idea of adopting a homogeneous kind of delivery of instruction. A serious fact-find mission needed to be conducted in a short space of time so that the suitable approach for ERT in each area could be adopted. There was also no harm in having more than one approach being available for a single geographical location so that learners would choose one that they felt to be suiting their physical environment and their economic standing. China did not restrict itself to only one method of delivering instruction but had more than 10 online platforms and other varied methods of delivering instruction, including many radio stations and four television channels. The Government of Zimbabwe should have also partnered with network providers like Econet, Telecel, Powertel and Netone to come up with immediate solutions that would lead to successful implementation of ERT. The government should have also understood that COVID-19 pandemic is a crisis within a crisis, because of the economic hardships that the country is facing, as such properly orchestrated modes of engagement in teaching and learning needed to be considered within the framework of readily available resources. During the crisis, all methods of teaching that conformed to the idea of remote teaching such as WhatsApp should have been officially adopted and used until the crisis was over. 


\section{Acknowledgements}

The authors would like to thank the research participants from selected schools in Matabeleland North and South provinces of Zimbabwe for their participation in this study and for their valuable information that made possible this article. Their names cannot be listed here for ethical reasons.

\section{Competing interests}

R.N. and B.P.T. have declared that no competing interests exist.

\section{Authors' contributions}

R.N. and B.P.T. contributed equally to this work.

\section{Ethical considerations}

This article followed all ethical standards for research without direct contact with human or animal subjects.

\section{Funding information}

This research received no specific grant from any funding agency in the public, commercial or not-for-profit sectors.

\section{Data availability}

The authors confirm that the data supporting the findings of this study are available within the article.

\section{Disclaimer}

The views and opinions expressed in this article are those of the authors and do not necessarily reflect the official policy or position of any affiliated agency of the authors.

\section{References}

Affouneh, S., Salha, S. \& Khlaif, Z.N., 2020, 'Designing quality e-learning environments for emergency remote teaching in coronavirus crisis', Interdisciplinary Journal of Virtual Learning in Medical Sciences 11(2), 1-3, viewed 29 June 2020, from https://www.researchgate.net/publication/341358623_Designing Quality_E-Learning_Environments_for_Emergency_Remote_Teaching_in_ Coronavirus_Crisis.

Alvarez, A., 2020, 'The phenomenon of learning at a distance through emergency remote teaching amidst the pandemic crisis', Asian Journal of Distance Education 15(1), 144-153. https://doi.org/10.5281/zenodo.3881529

Bates, T., 2020, Advice to those about to teach online because of the coronavirus, viewed 24 May 2020, from https://www.tonybates.ca/2020/03/09/advice-tothose-about-to-teach-online-because-of-the-corona-virus/.

Bouhnik, D. \& Deshen, M., 2014, 'WhatsApp goes to school: Mobile instant messaging between teachers and students', Journal of Information Technology Education: Research 13, 217-231. https://doi.org/10.28945/2051

Bozkurt, A. \& Sharma, R.C., 2020, 'Emergency remote teaching in a time of global crisis due to coronavirus pandemic', Asian Journal of Distance Education 15(1), i-vi. https://doi.org/10.5281/zenodo.3778083

Cauchemez, S., Van Kerkhove, M.D., Archer, B.N., Cetron, M., Cowling, B.J., Grove, P. et al., 2014, 'School closures during the 2009 influenza pandemic: National and local experiences', BMC Infectious Diseases 14(1), 207. https://doi. org/10.1186/1471-2334-14-207
Chronicle, 2020, COVID-19: Government launches radio lessons for pupils, viewed 06 June 2020, from https://www.chronicle.co.zw/covid-19-govt-launches-radiolessons-for-pupils/.

Creswell, J.W., 2017, Research design: Qualitative and mixed methods approaches, Sage, London.

Dorsey, B.J., 2006, 'Chapter 13: Equality opportunity in Zimbabwe: Past and future', in J. Megarry, S. Nisbet \& E. Hoyle (eds.), World yearbook of education 1981: Education of minorities, pp. 211-225, Routledge, London.

Hodges, C.B., Moore, S.L., Lockee, B.B. \& Bond, M.A., 2020a, 'Instructional design for emergency remote teaching (ERT) - Job aid', Leadership, Technology, and Human Development Faculty Publications Paper 119, viewed 29 June 2020 from https://doi.org/10.20429/10.1007_978-981-15-7869-4_3_1.

Hodges, C., Moore, S., Lockee, B., Trust, T. \& Bond, A., 2020b, The difference between emergency remote teaching and online learning, viewed 29 June 2020, from https://er.educause.edu/articles/2020/
remote-teaching-and-online-learning.

Huang, R.H., Liu, D.J., Tlili, A., Yang, J.F. \& Wang, H.H., 2020, Handbook on facilitating flexible learning during educational disruption: The Chinese experience in maintaining undisrupted learning in COVID-19 outbreak, Smart Learning Institute of Beijing national University, Beijing, viewed from https://alecso.org/nsite/ of Beijing natior

Ji, T., Chen, H.L., Xu, J., Wu, L.N., Li, J.J., Chen, K. \& Qin, G., 2020, 'Lockdown contained the spread of 2019 novel coronavirus disease in Huangshi city, China: Early epidemiological findings', Clinical Infectious Diseases CIAA 390 71(6), 1454-1460. https://doi.org/10.1093/cid/ciaa390

Kubatana, 2020, 'Apping to learn: Interview with ARTUZ about their WhatsApp school', viewed 21 April 2020, from https://kubatana.net/2020/04/21/apping-tolearn-interview-with-artuz-about-their-whatsapp-school/.

LaBonte, R., 2020, Emergency remote teaching: Resources, tools, and ideas, viewed 24 May 2020, from https://canelearn.net/emergency-remote-teaching/.

Lau, H., Khosrawipour, V., Kocbach, P., Mikolajczyk, A., Schubert, J., Bania, J. et al., 2020, 'The positive impact of lockdown in Wuhan on containing the COVID-19 outbreak in China', Journal of Travel Medicine 27(3), 1-7. https://doi:10.1093/ jtm/taaa037

McAleer, M., 2020, 'Prevention is better than the cure: Risk management of COVID-19', Journal of Risk and Financial Management 13(3), 46. https://doi. org/10.3390/jrfm13030046

Ostashewski, N. \& Reid, D., 2013, 'The networked learning framework: A model for networked professional learning utilising social networking sites', in J. Keengwe $\&$ L. Kyei-Blankson (eds.), Virtual mentoring for teachers: Online professional development practices, pp. 66-83, Information Science Reference, Hershey.

Roberts, T. \& Hernandez, K., 2019, 'Digital access is not binary: The 5'A's of technology access in the Philippines', The Electronic Journal of Information Systems in Developing Countries 85(4), e12084. https://doi.org/10.1002/isd2.12084

Ruzivo, 2019, Smart learning bringing 21st century to Zimbabwe, viewed 07 May 2020, from https://www.higherlifefoundation.com/ruzivo-smart-learningbringing-21st-century-learning-to-zimbabwe/.

Sahu, P., 2020, 'Closure of universities due to coronavirus disease 2019 (COVID-19): Impact on education and mental health of students and academic staff', Cureus 12(4), e7541. https://DOI10.7759/cereus.7541

Schlesselman, L.S., 2020, 'Perspectives from a teaching and learning center during emergency remote teaching', American Journal of Pharmaceutical Education 84(5), ajpe8142. https://doi.org/10.5688/ajpe8142

Sunday News, 2020, 'Pupils to receive lessons through radio', viewed 26 April 2020 from https://www.sundaynews.co.zw/pupils-to-receive-lessons-through-radio/.

Talidong, K.J.B., 2020. 'Implementation of emergency remote teaching (ERT) among Philippine teachers in Xi'an, China', Asian Journal of Distance Education 15(1), 196-201. https://doi.org/10.5281/zenodo.3881825

Toquero, C.M.D., 2020, 'Emergency remote teaching amid COVID-19: The turning point', Asian Journal of Distance Education 15(1), 185-188. https://doi. org/10.5281/zenodo.3881784

Trust, T. \& Whalen, J., 2020, 'Should teachers be trained in emergency remote teaching? Lessons learned from the COVID-19 pandemic', Journal of Technology and Teacher Education 28(2), 189-199.

UNICEF, 2020, Schools remain locked for more than 127 million children in Eastern and Southern Africa, viewed 04 May 2020, from https://www.unicef.org/esa/pressSouthern Africa, viewed 04 May 2020, from https://www.unicef.org/esa/press-
releases/schools-remain-locked-more-127-million-children-eastern-andreleases/schools-
southern-africa.

Viner, R.M., Russell, S.J., Croker, H., Packer, J., Ward, J., Stansfield, C. et al., 2020, 'School closure and management practices during coronavirus outbreaks including COVID-19: A rapid systematic review', The Lancet Child \& Adolescent Health 4(5), 397-404. https://doi.org/10.1016/S2352-4642(20)30095-X

Wang, C., Cheng, Z., Yue X.G. \& McAleer, M., 2020, 'Risk management of COVID-19 by universities in China', Journal of Risk and Financial Management 13(2), 36. https:// doi.org/10.3390/jrfm13020036

Zhang, W., Wang, Y., Yang, L. \& Wang, C., 2020, 'Suspending classes without stopping learning: China's education management policy in the COVID-19 outbreak' Journal of Risk and Financial Management 13(55), 1-6. https://doi:10.3390/ jrfm13030055 